\title{
Studi fenomenologi makna pengembangan Industri Rumah Tangga (IRT) rengginang bagi buruh perempuan di Desa Sambigede
}

\author{
Ifan Andriado, Anis Khoirun Nisa, Dini Rahmawati Agustin, Dwi Mulyani Indrawati, \\ Hamida Zama Rahmatillah, Elya Kurniawati* \\ Universitas Negeri Malang, Jl. Semarang No. 5 Malang, Jawa Timur, Indonesia \\ * Penulis korespondensi, Surel: elya.kurniawati.fis@um.ac.id
}

Paper received: 03-02-2021; revised: 15-02-2021; accepted: 28-02-2021

\begin{abstract}
Abstrak
Globalisasi membawa pengaruh kuat terhadap perkembangan ekonomi masyarakat. Hal ini ditandai dengan munculnya berbagai industri pada masyarakat desa, salah satunya Industri Rumah Tangga (IRT) rengginang di Desa Sambigede, Kecamatan Sumberpucung, Kabupaten Malang. Dalam proses produksinya, IRT rengginang ini mempekerjakan buruh yang mayoritas perempuan. Penelitian ini bertujuan untuk menjelaskan makna pengembangan Industri Rumah Tangga (IRT) rengginang bagi buruh perempuan di Desa Sambigede. Penelitian ini dikaji menggunakan metode penelitian kualitatif dengan pendekatan fenomenologi. Subjek penelitian berjumlah lima orang buruh yang ditentukan dengan cara purposive sampling dan dilanjutkan dengan snowball sampling. Teknik pengumpulan data dilakukan dengan cara observasi, wawancara, dan dokumentasi. Keabsahan data dalam penelitian ini diperoleh menggunakan teknik triangulasi sumber dan metode. Teknik analisis data yang digunakan adalah pengumpulan data, reduksi data, penyajian data, dan verifikasi atau kesimpulan. Penelitian ini dikaji menggunakan teori Fenomenologi oleh Huserl. Hasil dari penelitian ini menunjukkan bahwa terdapat lima makna Industri Rumah Tangga (IRT) rengginang bagi buruh perempuan, antara lain: 1) sebagai mata pencaharian utama, 2) sebagai pekerjaan sampingan, 3) sebagai sarana memperluas relasi, 4) sebagai aktivitas pengisi waktu luang, dan 5) sebagai sarana untuk meneruskan usaha keluarga.
\end{abstract}

Kata kunci: industri rumah tangga; buruh perempuan; teori fenomenologi.

\section{Pendahuluan}

Berkembangnya ilmu pengetahuan dan teknologi manusia memicu munculnya upayaupaya pembaharuan dalam memanfaatkan hasil perkembangan tersebut. Perkembangan ini dipicu oleh dorongan kuat dari proses globalisasi. Secara bahasa, globalisasi diambil dari kata "global" yang artinya menyeluruh. Globalisasi memunculkan berbagai tantangan dan permasalahan yang harus segera diatasi dan dipecahkan dalam menanggapi kepentingan manusia. Globalisasi sendiri muncul dari istilah dua puluh tahun lalu yang artinya proses yang begitu mudah diterima dan dikenal oleh masyarakat seluruh dunia. Wacana globalisasi yang mampu mengubah perkembangan ilmu pengetahuan dan teknologi membuat proses ini dianggap mampu mengubah sisi kehidupan secara mendasar (Nurhaidah \& Musa, 2015).

Akibat dari berkembangnya pengetahuan manusia inilah, maka semakin berkembang pula kebutuhan manusia dan menuntut untuk dipenuhi. Banyaknya kebutuhan hidup yang harus dipenuhi mendorong seseorang untuk bekerja guna memperoleh penghasilan. Penghasilan inilah yang digunakan untuk memenuhi kebutuhan seperti kebutuhan pokok dan kebutuhan lainnya. Selain itu, seseorang bekerja karena ingin mencapai kehidupan yang layak. Untuk mencapai hal tersebut tentunya seseorang harus memiliki semangat kerja yang tinggi. Dari latar belakang tersebut, muncullah sebuah upaya peningkatan ekonomi dalam bentuk 
industrialisasi baik berskala makro hingga yang dilakukan dalam skala rumah tangga. Menurut Nurgandini (2014) Industri merupakan salah satu sektor yang muncul dan berkembang di daerah perdesaan setelah sektor pertanian. Menurut UU Nomor 5 Tahun 1984, industri adalah kegiatan ekonomi yang mengolah bahan mentah, bahan baku, barang setengah jadi, dan barang jadi. Pengolahan ini diharapkan dapat meningkatkan nilai jual yang lebih tinggi, termasuk kegiatan kerja rancang bangun dan rekayasa industri. Berdasarkan jumlah karyawan, industri dibedakan menjadi empat skala: 1) industri rumah tangga (terdiri dari 1-4 orang karyawan), 2) industri kecil (terdiri dari 5-19 orang karyawan), 3) industri sedang/menengah (terdiri dari 100 orang atau lebih karyawan). Industri rumah tangga dan industri kecil merupakan industri yang mayoritas berkembang di daerah perdesaan. Salah satu daerah perdesaan yang dimaksud adalah Desa Sambigede. Desa Sambigede adalah salah satu desa yang berada di Kecamatan Sumberpucung, Kabupaten Malang, yang memiliki luas wilayah $2.267 \mathrm{Ha}$, seperti tergambar pada grafik di bawah:

Tabel 1. Luas Desa/Kelurahan (Ha) di Kecamatan Sumberpucung Tahun 2018

\begin{tabular}{cll}
\hline No. & Nama Desa & Luas Daerah (Ha) \\
\hline 1. & Karangkates & 756,70 \\
2. & Sumberpucung & 609,40 \\
3. & Jatiguwi & 459,10 \\
4. & Sambigede & $2.267,00$ \\
5. & Senggreng & 584,50 \\
6. & Ternyang & 505,79 \\
7. & Ngebruk & 503,75 \\
\hline
\end{tabular}

Sumber: Badan Pusat Statistik Kecamatan Sumberpucung, 2019

Berdasarkan tabel di atas, menunjukkan bahwa luas wilayah Desa Sambigede kurang lebih tiga kali lipat dari luas desa lainnya di Kecamatan Sumberpucung. Desa ini terdiri dari 9 Rukun Warga (RW) dan 29 Rukun Tetangga (RT) (BPS, 2019). Desa Sambigede memiliki tingkat kepadatan penduduk sebesar $13,44 \%$ dan memiliki luas lahan persawahan sebesar $2.190 \mathrm{Ha}$. Seperti data pada tabel berikut:

Tabel 2. Luas Desa/Kelurahan Menurut Jenis Lahan (Ha) Tahun 2018

\begin{tabular}{lll}
\hline No. & Nama Desa & Lahan Sawah (Ha) \\
\hline 1. & Karangkates & 192,50 \\
2. & Sumberpucung & 307,80 \\
3. & Jatiguwi & 297,70 \\
4. & Sambigede & $2.190,00$ \\
5. & Senggreng & 341,00 \\
6. & Ternyang & 334,80 \\
7. & Ngebruk & 214,20 \\
\hline
\end{tabular}

Sumber: Badan Pusat Statistik Kecamatan Sumberpucung, 2019.

Dari data di atas terlihat bahwa Desa Sambigede memiliki luas lahan sawah kurang lebih delapan kali lebih besar dari luas lahan sawah yang dimiliki oleh desa lainnya dalam lingkup Kecamatan Sumberpucung. Berdasarkan data tersebut, menggambarkan bahwa potensi sawah menjadi prioritas utama bagi kehidupan masyarakat desa Sambigede dan menjadikannya sebuah mata pencaharian untuk menopang kehidupan ekonomi masyarakat. Dari kondisi geografis inilah, yang membuat mayoritas warga Desa Sambigede bekerja dalam sektor pertanian. Di sisi lain, sebagian masyarakat tidak hanya bekerja di sektor pertanian tetapi 
bekerja di sektor industri rumah tangga yang mengolah salah satu hasil pertanian yaitu beras ketan. Di desa ini muncul banyak sekali industri rumah tangga yang memproduksi makanan olahan berbahan dasar ketan, salah satunya rengginang. Bahkan desa ini menjadi desa sentra produk rengginang di Kabupaten Malang.

Dari kemunculan proses industrialisasi inilah, yang memicu terciptanya pemetaan kerja yaitu pemilik modal dan buruh. Buruh dalam kerangka ekonomi memiliki peran sebagai tenaga kerja untuk memproduksi barang dan jasa, dan menggerakkan aset pemilik modal. Tanpa adanya buruh, sistem ekonomi tidak akan berjalan baik seperti yang diharapkan. Tidak berjalannya sistem ekonomi inilah yang nantinya akan berdampak kepada sistem sosial, antara lain membentuk suatu pola sosial, menciptakan perubahan, dan menjalankan agenda sosial (Zuhaena, 2016). Hal ini tercermin dalam Industri Rumah Tangga (IRT) rengginang yang ada di Desa Sambigede, di mana mayoritas buruh atau karyawan IRT adalah perempuan. Buruh perempuan dalam IRT rengginang ini bekerja pada bagian pencetakan rengginang dan pengemasan. Dari kesempatan kerja inilah yang membuat mayoritas perempuan di Desa Sambigede memilih bekerja atau memutuskan menjadi buruh di industri rumah tangga rengginang. Fenomena ini sama halnya yang dikatakan oleh Pradhanawati (2018), bahwa dewasa ini semakin banyak buruh perempuan yang terjun dalam dunia industrialisasi baik skala makro maupun skala industri rumah tangga. Kendati itu, maka membuktikan bahwa peran perempuan saat ini semakin meningkat seiring dengan perkembangan pembangunan khususnya di bidang ekonomi yang dibuktikan melalui dibukanya peluang kerja selebarlebarnya bagi perempuan.

Merujuk pada kajian penelitian terdahulu yang dilakukan oleh Puspitasari (2012), Nurgandini (2014), dan Muhar (2015), yang membahas tentang pengembangan Industri Rumah Tangga (IRT). Tiga kajian penelitian terdahulu tersebut melihat pengembangan industri rumah tangga dari kacamata modal sosial yang dijalinnya. Hasil dari penelitian tersebut sepakat menyatakan bahwa modal sosial sangat penting dalam proses pengembangan industri karena dengan modal sosial inilah yang dapat mempengaruhi tingkat keberhasilan sebuah industri rumah tangga. Sedangkan kajian penelitian terdahulu yang dilakukan oleh Jemadi (2014), Susilawati (2017), dan Putri (2018) yang membahas tentang strategi pengembangan industri rumah tangga dari kacamata aksesibilitas pemasaran. Hasil dari ketiga penelitian tersebut sepakat menyatakan bahwa strategi aksesibilitas pemasaran dicapai dengan cara memperluas jaringan pemasaran seperti jaringan berskala mikro dan messo.

Dari kedua kacamata kajian tersebut yaitu hanya mencoba melihat dari sisi modal sosial dan strategi aksesibilitas pemasaran pengembangan Industri Rumah Tangga (IRT), belum terdapat kajian spesifik memberikan yang perhatian pada kacamata buruh perempuan. Oleh karena itu, untuk mengisi kekosongan kajian literasi ini, peneliti tertarik untuk mengkaji lebih dalam dengan melihat pengembangan IRT dari sudut pandang buruh perempuan melalui pendekatan fenomenologi. Penggunaan pendekatan ini diharapkan mampu mendeskripsikan berbagai pola tentang pemaknaan buruh perempuan terhadap IRT rengginang tersebut. Dari sinilah sisi kebaharuan (novelty) muncul, yaitu dengan melakukan penelitian yang berjudul "Studi Fenomenologi Makna Pengembangan Industri Rumah Tangga (IRT) Rengginang bagi Buruh Perempuan di Desa Sambigede". Penelitian ini bertujuan untuk menjelaskan makna pengembangan Industri Rumah Tangga (IRT) rengginang bagi buruh perempuan di Desa Sambigede. 


\section{Metode}

Penelitian ini dikaji menggunakan metode penelitian kualitatif dengan pendekatan fenomenologi. Penelitian dilakukan di Desa Sambigede, Kecamatan Sumberpucung, Kabupaten Malang. Subjek penelitian ditentukan dengan cara purposive sampling dan dilanjutkan dengan snowball sampling. Dari cara inilah, peneliti mendapat lima informan sebagai subjek penelitian yaitu buruh perempuan pada IRT rengginang (B. Yatemi, B. Katri, B. Ngatin, B. Rina, dan B. Melik). Teknik pengumpulan data dilakukan dengan cara observasi, wawancara mendalam (indepth-interview), dan dokumentasi. Keabsahan data dalam penelitian ini diperoleh menggunakan teknik triangulasi sumber dan metode. Teknik analisis data yang digunakan adalah analisis data interaktif yang terdiri dari pengumpulan data (data collection), reduksi data (data reduction), penyajian data (data display), verifikasi dan penegasan kesimpulan (verification and conclusion drawing). Penelitian ini menggunakan teori Fenomenologi oleh Huserl sebagai pisau analisis.

\section{Hasil dan Pembahasan}

\subsection{Makna Pengembangan Industri Rumah Tangga (IRT) Rengginang bagi Buruh Perempuan di Desa Sambigede}

Industri Rumah Tangga (IRT) rengginang merupakan industri yang memproduksi makanan olahan berbahan dasar beras ketan yaitu rengginang. Industri ini sudah berkembang lama di Desa Sambigede. Kemunculan industri ini merupakan reaksi dari potensi alam yang dimiliki oleh Desa Sambigede yaitu luasanya lahan sawah yang menghasilkan hasil pertanian melimpah, mulai dari bahan dasar makanan pokok seperti padi, jagung, dan tebu, desa ini juga menghasilkan berbagai jenis sayuran seperti sawi, kacang panjang, terong, brokoli, cabai, dan lain sebagainya. Dari potensi desa akan hasil pertanian inilah, yang memunculkan inisiatif masyarakat setempat untuk mengembangkan inovasi bahan dasar makanan pokok menjadi sebuah produk makanan ringan yang memiliki nilai ekonomis. Produk makanan ringan yang dimaksud adalah rengginang. Dalam proses produksinya, industri rumah tangga yang ada di Desa Sambigede memiliki rata-rata buruh atau karyawan sebanyak 1-5 orang buruh. Buruh yang bekerja pada IRT rengginang ini mayoritas adalah buruh perempuan. Buruh perempuan ini bekerja pada bagian pencetakan rengginang sekaligus pada pengemasan. Dari hasil wawancara yang dilakukan, peneliti merumuskan lima makna dari pengembangan Industri Rumah Tangga (IRT) rengginang bagi perempuan, antara lain:

\subsubsection{Industri Rumah Tangga (IRT) Rengginang Sebagai Mata Pencaharian Utama}

Pada dasarnya setiap manusia memiliki kebutuhan yang harus dipenuhi dalam melangsungkan hidup. Untuk memenuhi kebutuhannya, maka salah satu upaya yang dibutuhkan adalah dengan jalan bekerja. Salah satu pekerjaan untuk memenuhi kebutuhan hidup adalah menjadi buruh dalam sebuah industri rumah tangga. Hal inilah yang seperti dilakukan oleh informan penelitian ini. Namun ada salah seorang informan yang memaknai IRT rengginang ini sebagai mata pencaharian utama. Hal ini dilatarbelakangi oleh status perempuan tersebut yaitu janda, di mana ia harus bekerja dengan jerih payahnya sendiri untuk menopang kebutuhan hidup. Salah satu pekerjaan yang bisa dilakukannya adalah menjadi buruh di salah satu IRT rengginang di Desa Sambigede. Hal tersebut sesuai dengan hasil wawancara seperti di bawah ini: 
"Ya bagaimana ya, mas. Saya hidup sendiri, saya janda ditinggal meninggal suami saya. Jadi, mau tidak mau ya saya harus mencari penghidupan sendiri untuk menopang hidup saya. Meskipun saya mempunyai anak, saya tidak mau merepotinya. Selama saya mampu bekerja, ya saya lakukan apa saja itu asal menghasilkan uang untuk memenuhi kebutuhan. Kebetulan sekali industri ini mencari buruh mencetak rengginang, dan saya mempunyai kemampuan itu. Itulah alasan mengapa saya memilih menjadi buruh pencetak rengginang di sini. Kalau dibilang ini pekerjaan utama, ya memang benar." (Hasil wawancara B. Katri, Informan 2)

Dari pemaparan tersebut membuktikan bahwa keberadaan Industri Rumah Tangga (IRT) rengginang dimaknai sebagai mata pencaharian utama buruh perempuan.

\subsubsection{Industri Rumah Tangga (IRT) Rengginang Sebagai Pekerjaan Sampingan}

Seperti layaknya peran perempuan dalam konteks keluarga, di mana peran perempuan berada dalam sektor domestik seperti mengurus rumah, mengurus anak, dan lain sebagainya. Peran seorang laki-laki dalam konteks keluarga adalah mencari nafkah. Konsep tersebut masih berlaku pada buruh perempuan di industri rumah tangga. Namun, konsep itu tidak berlaku secara menyeluruh, karena buruh perempuan tersebut telah membuktikan bahwa tidak selamanya perempuan ada di sektor domestik. Mereka mencoba keluar dan mencoba mencari pekerjaan yang dianggap mampu membantu perekonomian keluarga. Hal ini dilatarbelakangi oleh faktor ekonomi yang cenderung minim dalam rumah tangga. Oleh karena itu, perempuan sebagai istri memutuskan untuk membantu laki-laki (suami) dalam mencari penghasilan tambahan dalam memenuhi kebutuhan keluarga. Dan pada dasarnya perempuan yang memaknai industri rumah tangga rengginang sebagai pekerjaan sampingan adalah perempuan yang sudah memiliki pekerjaan tetap dalam sebuah sektor tertentu.

"Kalau saya sendiri sebenarnya sudah mempunyai pekerjaan yang relatif tetap mas, di salah satu pabrik rokok. Tapi kerja saya cuma dari hari senin sampai jumat. Untuk hari sabtu dan minggu libur. Ya daripada di rumah tidak menghasilkan apa-apa mending ya ikut bekerja jadi buruh disini saja. Meskipun upahnya tidak sebanding seperti upah pabrik yang saya kerja, tetapi setidaknya upah jadi buruh di sini bisa jadi buat tambal kebutuhan dapur." (Hasil wawancara B. Yatemi, Informan 1)

Dari pemaparan tersebut membuktikan bahwa keberadaan Industri Rumah Tangga (IRT) dimaknai sebagai pekerjaan sampingan buruh perempuan.

\subsubsection{Industri Rumah Tangga (IRT) Rengginang Sebagai Sarana Untuk Memperluas Relasi Sosial}

Dalam sebuah Industri Rumah Tangga (IRT) merupakan tempat berkumpul para buruh dengan berbagai motif kerja. Dari perkumpulan ini, akan terjadi sebuah komunikasi dan proses interaksi. Semakin sering intensitas antar buruh berinteraksi, maka semakin tinggi pula relasi sosial yang dibangun. Begitu pun sebaliknya, semakin jarang intensitas interaksi, maka semakin rendah pula relasi sosial yang dibangun. Dari konsep ini sangat jelas bahwa relasi sosial atau hubungan sosial sangat penting bagi kehidupan bermasyarakat. Semua orang memahami bahwa kesuksesan seseorang bukan hanya karena otak orang tersebut sendiri, tetapi juga karena dorongan orang-orang sekitar yang selalu memberi dukungan hingga tercapai titik kesuksesan tersebut. Dalam konteks buruh perempuan di IRT rengginang, mereka memanfaatkan keberadaan IRT sebagai ajang untuk saling mempererat hubungan 
antar tetangga. Tidak jarang juga, dari jalinan relasi yang kuat, mereka memanfaatkan untuk mencari informasi pekerjaan bilamana IRT yang dikerjai sekarang sudah berhenti operasi sementara. Dari sinilah terbukti jika rasa kebersamaan (mutual understanding) terjalin dengan baik antar buruh perempuan IRT rengginang. Pernyataan berikut didukung oleh keterangan salah seorang informan, sebagai berikut:

"Begini ya, mas. Sebenarnya kalau urusan upah itu nomor 2 nomor 3, toh lagian upah dari buruh ini juga tidak seberapa. Yang terpenting itu teman atau jaringan. Bahkan saya bisa bekerja di sini, itu juga karena teman (tetangga) yang memberi informasi. Dan pengalaman saya, saya sering pindah-pindah IRT karena IRT tempat saya bekerja dulu, berhenti sementara, tapi berhubung ada teman yang memberi informasi jadi saya pindah di IRT ini, tidak menutup kemungkinan itu terjadi seterusnya. Jadi menurut saya IRT ini adalah tempat menambah teman." (Hasil wawancara B. Rina, Informan 4)

Dari pemaparan tersebut membuktikan bahwa keberadaan Industri Rumah Tangga (IRT) rengginang dimaknai sebagai sarana untuk memperluas relasi sosial bagi buruh perempuan.

\subsubsection{Industri Rumah Tangga (IRT) Rengginang Sebagai Alternatif Aktivitas Pengisi Waktu Luang}

Seperti halnya konsep keluarga pada umumnya di mana mayoritas perempuan (istri) berada dalam sektor domestik. Dalam sebuah istilah mengatakan bahwa istri adalah teman dapur. Hal ini juga tergambar pada mayoritas istri di Desa Sambigede sebelum adanya pertumbuhan Industri Rumah Tangga (IRT) rengginang yang begitu pesat seperti sekarang. Namun, setelah banyak IRT rengginang bermunculan, peran istri yang tadinya hanya di sektor domestik, sekarang mulai bergeser untuk memutuskan mengambil peran ganda yaitu mulai bekerja menjadi buruh pada IRT rengginang yang beroperasi di desa ini. Ada berbagai motif mereka memutuskan bekerja salah satunya adalah untuk mengisi kegiatan waktu luang dengan aktivitas yang positif dan produktif. Keterangan tersebut didukung oleh salah seorang informan, sebagai berikut:

"Menjadi buruh seperti ini itu upahnya juga tidak seberapa sebenarnya mas. Cuma bisa untuk memenuhi kebutuhan sembako. Tapi ya bagaimana lagi, dari pada di rumah nganggur dan tidak melakukan aktivitas apa-apa, mending jadi buruh kayak begini. Kalau masalah mengurus anak, kan waktu mencetak rengginang seperti ini pada waktu anak masih sekolah, sepulang anak sekolah, pekerjaan ini sudah selesai, jadi gantian mengurus anak tidak, kerja lagi. Jadi intinya, memanfaatkan peluang untuk lebih produktif dan menghasilkan upah. Jadi kalau dibilang untuk mengisi waktu luang ya benar juga, tapi saya lebih setuju kalau dibilang pengisi waktu luang yang menghasilkan upah." (Hasil wawancara B. Melik, Informan 5)

Dari pemaparan tersebut membuktikan bahwa keberadaan Industri Rumah Tangga (IRT) rengginang dimaknai sebagai alternatif aktivitas pengisi waktu luang bagi buruh perempuan. 


\subsubsection{Industri Rumah Tangga (IRT) Rengginag Sebagai Sarana Meneruskan Usaha Keluarga}

Seperti yang dipaparkan sebelumnya, bahwa terdapat banyak motif para perempuan menjadi buruh IRT rengginang, salah satunya untuk meneruskan usaha keluarga. Yang dimaksud meneruskan usaha keluarga adalah para buruh memanfaatkan pekerjaannya untuk mengumpulkan modal, yang suatu saat nanti akan digunakan untuk membuka IRT rengginang sendiri, seperti yang dilakukan oleh orang tuanya dulu atau keluarganya dulu. Biasanya buruh perempuan yang bermotif seperti ini adalah buruh perempuan yang memiliki bekal banyak tentang proses produksi hingga pemasaran yang didapatkan dari keluarganya dahulu. Namun, bekal pengetahuan itu belum bisa terealisasikan karena kurangnya modal (biaya produksi) untuk mendirikan IRT rengginang sendiri. Dengan menjadi buruh di salah satu IRT rengginang yang ada di Desa Sambigede, mereka dapat mengumpulkan upah sekaligus pengetahuan tambahan tentang proses produksi dan distribusi yang sangat bermanfaat untuk dirinya di kemudian hari. Hal ini sesuai dengan pernyataan salah seorang informan, sebagai berikut:

"Keluarga saya dulu pernah membuka IRT seperti ini, tetapi dikelola secara keluarga, jadi tidak memiliki karyawan dari luar. Maksudnya kalau proses mencetak seperti ini, yang melakukan adalah saya dan saudara-saudara saya pada waktu itu. Jadi sedikit-sedikit saya tahu lah kalau masalah produksi dan pemasarannya. Namun, sudah sekitar 10 tahun ini, IRT keluarga saya tidak beroperasi lagi semenjak orang tua saya meninggal. Jadi, mau tidak mau saya mencari kerja. Kebetulan IRT ini mencari buruh, dan kebetulan sekali saya bisa mencetak rengginang, jadi saya kerja di sini. Hitung-hitung bisa mengumpulkan uang dari sini, untuk mendirikan IRT rengginang sendiri di suatu hari nanti, meskipun kecil-kecilan. Ya intinya saya kepingin meneruskan usaha IRT yang telah didirikan oleh orang tua saya dulu." (Hasil wawancara B. Ngatin, Informan 3)

Dari pemaparan tersebut membuktikan bahwa keberadaan Industri Rumah Tangga (IRT) rengginang dimaknai sebagai sarana untuk meneruskan usaha keluarga bagi buruh perempuan.

\subsection{Makna Pengembangan Industri Rumah Tangga (IRT) Rengginang bagi Buruh Perempuan di Desa Sambigede Menggunakan Perspektif Teori Fenomenologi oleh Huserl}

Pada dasarnya, peneliti telah merumuskan makna IRT rengginang bagi para buruh perempuan, antara lain sebagai mata pencaharian utama, sebagai pekerjaan sampingan, sebagai sarana untuk memperluas relasi, sebagai alternatif aktivitas pengisi waktu luang, dan sebagai saran untuk meneruskan usaha keluarga. Dari makna-makna yang diberikan oleh para buruh perempuan IRT rengginang tersebut dapat dikaji dengan teori fenomenologi oleh Huserl. Menurut Huserl, teori fenomenologi menuntut kita untuk kembali kepada benda-benda itu sendiri, objek harus diberikan kesempatan untuk berbicara guna mencari hakikat fenomena atau gejala. Selain itu, kesadaran bukan bagian dari kenyataan, dia menolak bipolarisasi antara kesadaran dan alam, antara subyek dan objek. Kesadaran tidak akan pernah menemukan objek-objek, tetapi objek-objek diciptakan oleh kesadaran (Upe, 2010). Dengan dilakukannya kajian menggunakan fenomenologi ini, terdapat tiga reduksi untuk mencapai realitas fenomena, yaitu: 


\subsubsection{Reduksi Fenomenologis}

Huserl berpendapat bahwa reduksi fenomenologis menempatkan alam nyata atau menyisihkannya agar ia tampil ke dalam kesadaran (Zubaedi dkk, 2007). Pada reduksi ini, sikap peneliti dituntut untuk objektif dalam melihat sebuah fenomena atau gejala termasuk yang berkaitan dengan teori, kebiasaan, atau pandangan yang membuat peneliti melihat sesuatu dalam kesadarannya sendiri, sehingga yang timbul dalam kesadaran adalah fenomena itu sendiri. Reduksi fenomenologi menyatakan realita akan muncul dari dalam kesadaran itu sendiri. Kesadaran tersebut dipaparkan lebih lanjut berupa tindakan. Dalam konteks buruh perempuan pada IRT rengginang ini, para perempuan ini memiliki kesadaran bahwa dalam konteks keluarga, mereka keluar dari perannya (bekerja hanya dalam sektor domestik). Namun, bukan berarti mereka keluar dari peran sepenuhnya. Mereka melakukan pekerjaan tersebut ketika anak-anaknya masih sekolah, sepulang anaknya sekolah mereka (buruh perempuan) kembali berperan ke sektor domestik keluarganya yaitu dengan tidak menjadi buruh lagi, tetapi mengurus anak-anaknya di rumah seperti layaknya ibu rumah tangga lainnya Hal tersebut terbukti dari keterangan dari salah seorang informan yang memaknai keberadaan IRT rengginang sebagai alternatif aktivitas pengisi waktu luang (Informan 5).

\subsubsection{Reduksi Eidetisi atau Eidetik}

Dalam reduksi Eidetik berusaha menyingkirkan pengetahuan baik yang didapat dari sumber lain, teori maupun hipotesis yang sudah ada tentang objek yang diselidiki (Hamersma, 1983). Dalam konteks reduksi ini, realitas yang sebenarnya menunjukkan bahwa fenomenologi hasil pengamatan yang dilakukan secara berurutan harus dapat dijadikan satu. Dalam konteks buruh perempuan IRT rengginang, menurut reduksi ini menunjukkan bahwa perempuan yang ikut serta memilih menjadi buruh pada sebuah IRT rengginang, tidak dapat dipisahkan dari makna IRT rengginang itu sendiri. Para perempuan menganggap bahwa dengan bekerja menjadi buruh pada IRT rengginang mampu memberikan keuntungan baginya dan dapat menghasilkan uang. Menurut Hardiman (2003), makna itu muncul dan dihasilkan dari kesadaran para buruh perempuan sehingga antara makna dan kesadaran itu saling berkaitan dan tidak dapat dipisahkan. Hal tersebut terbukti ketika beberapa perempuan memaknai keberadaan IRT rengginang sebagai mata pencaharian utama (Informan 2), dan pekerjaan sampingan (Informan 2), atau sebagai sarana untuk meneruskan usaha keluarga (Informan 3).

\subsubsection{Reduksi Tradesental}

Reduksi ini disebut fenomenologi karena dunia ini pada dasarnya adalah bentuk transformasi dari fenomena yang murni. Konsep intensionalitas kesadaran Huserl yaitu bahwa keberadaan subjek dan objek tidak dapat terpisahkan dan bersifat interaktif, di mana masingmasing hanya dapat dimengerti dari penjelasan yang lain. Setiap ojek merupakan ojek dari beberapa subjek, dan setiap subjek merupakan bagian dari objek intensionalitasnya (Zeitlin, 1995). Dalam konteks buruh perempuan IRT rengginang, menurut reduksi fenomenologi trasendental Huserl, di mana subjek dan objek tidak dapat dipisahkan dan bersifat interaktif. Para buruh perempuan dengan kondisi lingkungan (tetangga atau teman) yang saling memberikan pengaruh sehingga tidak dapat dipisahkan, yang mana para perempuan yang bekerja menjadi buruh pada awalnya mendapat informasi dari teman sesama buruh. Oleh karena itu ada salah seorang informan yang menyatakan bahwa Industri Rumah Tangga (IRT) 
rengginang dimaknai sebagai sarana memperluas relasi sosial. Karena mereka sadar bahwa peranan relasi yang dijalin antar teman atau tetangga sangatlah besar dan berguna bagi kehidupannya (Informan 4).

\section{Simpulan}

Globalisasi membawa pengaruh yang sangat besar terhadap kemunculan industri di rural area atau daerah pedesaan. Industri ini muncul dalam skala makro hingga ke skala yang paling kecil yaitu industri rumah tangga. Kemunculan industri di daerah desa, diharapkan mampu meningkatkan kondisi perekonomian masyarakat desa dalam memenuhi kebutuhan hidup. Salah satu industri yang muncul di Desa Sambigede adalah Industri Rumah Tangga (IRT) rengginang. IRT rengginang merupakan industri yang memproduksi makanan olahan berbahan dasar beras ketan yaitu rengginang. Industri ini sudah berkembang lama di Desa Sambigede. Kemunculan industri ini merupakan reaksi dari potensi alam yang dimiliki oleh Desa Sambigede. Dari potensi desa akan hasil pertanian inilah, yang memunculkan inisiatif masyarakat setempat untuk mengembangkan inovasi bahan dasar makanan pokok menjadi sebuah produk makanan ringan yang memiliki nilai ekonomis. Produk makanan ringan yang dimaksud adalah rengginang. Dalam proses produksinya, industri rumah tangga yang ada di Desa Sambigede memiliki rata-rata buruh atau karyawan sebanyak 1-5 orang buruh. Buruh yang bekerja pada IRT Rengginang ini mayoritas adalah buruh perempuan. Dari hasil wawancara yang dilakukan, peneliti merumuskan lima makna dari pengembangan Industri Rumah Tangga (IRT) rengginang bagi buruh perempuan, antara lain: 1) sebagai mata pencaharian utama; 2) sebagai pekerjaan sampingan; 3) sebagai sarana untuk memperluas relasi sosial; 4) sebagai alternatif aktivitas pengisi waktu luang; 5) sebagai sarana untuk meneruskan usaha keluarga. Adapun pemaknaan ini dapat dianalisis menggunakan teori fenomenologi oleh Huserl dengan memperhatikan tiga reduksi dam mengenali sebuah fenomena, antara lain 1) reduksi fenomenologis; 2) reduksi eidetisi/eidetik; 3) reduksi tradesental.

\section{Daftar Rujukan}

Badan Pusat Statistik. (2019). Kecamatan Sumberpucung Dalam Angka $2019 . \quad$ [online]. (http://www.bps.go.id), diakses tanggal 30 September 2020.

Hamersma, Harry. (1983). Tokoh -Tokoh Filsafat Barat Modern. Jakarta: PT Garamedia.

Hardiman, F.Budi. (2003). Melampaui Positivisme dan Modernitas: Diskursus Filosofis tentang Metode Ilmiah dan Problem Modernitas. Yogyakarta: Kanisius.

Jemadi., Sugeng, B. (2014). Strategi Kelompok Buruh Perempuan Dalam Memanfaatkan Modal Sosial Untuk Meningkatkan Aksesibilitas Pasar (Studi di Kelompok Buruh Perempuan "Tani Rejo" dalam Mengakses Industri Emping Melinjo di Kecamatan Limpung, Kabupaten Batang, Provinsi Jawa Tengah). Jurnal Maksipreneur, 4(1), 69-97.

Muhar, Ani M., Setiawan, T. (2015). Peran Modal Sosial, Kereligian, dan Perilaku Moral dalam Membentuk Kinerja Usaha Mikro dan Kecil dengan Aspek Demografi Sebagai Variabel Pengendali. Jurnal Dinamika Akuntansi Dan Bisnis, 2(1), 1-13.

Nurgandini, P. (2014). Peran Modal Sosialm Dalam Kecil Tas di Desa Bojong Rangkas Kecamatan Ciampea Bogor. Skripsi, Bogor: Institut Pertanian Bogor.

Nurhaidah., Musa, M. (2015). Dampak Pengaruh Globalisasi Bagi Kehidupan Bangsa Indonesia. Jurnal Pesona Dasar, 3(3), 1-14.

Pradhanawati, A. (2018). Peran Buruh Perempuan dalam Keluarga. Semarang: Amazing Book Creative.

Puspitasari, D.C. (2012). Modal Sosial Dalam Peran Penguatan Ekonomi Keluarga. Jurnal Pemikiran Sosiologi, Volume 1(2). 
Jurnal Integrasi dan Harmoni Inovatif Ilmu-Ilmu Sosial (JIHI3S), 1(2), 2021, 125-134

Putri, Zeni E. (2018). Pemanfaatan Jaringan Sosial dalam Pengembangan Usaha oleh Pelaku UMKM (Studi Kasus: 8 Pelaku UMKM Pada Sentra Makanan Rendang di Kelurahan Sungai Durian, Kecamatan Lamposi Tigo Nagari, Kota Payakumbuh). Jurnal Sains Sosial Dan Humaniora, Volume 2(1), 1-16.

Susilawati., Yakin, Saeful H. (2017). Analisis Strategi Pemasaran Makanan Tradisional (Studi Kasus Industri Rengginang di Kecamatan Sakra Pusat). Jurnal Pendidikan Ekonomi Dan Kewirausahaan, Volume 1(1).

Upe, A. (2010). Tradisi Aliran Dalam Sosiologi: Dari Filosofi Positivistik ke Post Positivistik. Jakarta: PT Raja Grafindo Persada.

Zeitlin, Irving. M. (1995). Memahami Kembali Sosiologi: Kritik Terhadap Teori Sosiologi Kotemporer. Yogyakarta: Gajah Mada University Press.

Zubaedi. (2007). Wacana Pembangunan Alternatif. Yogyakarta: Ar-Rizz Media.

Zuhaena, F. (2016). Keterwakilan Perempuan dalam Serikat Buruh. Jurnal, Purwokerto: Fakultas Ekonomi, Universitas Wijaya Kusuma Purwokerto. 